\title{
First evaluation of the serum level of anti-hepatitis B surface antigen after vaccination in Libya
}

A. Madour, ${ }^{1}$ A. Alkout $^{2}$ and S. Vanin ${ }^{3}$

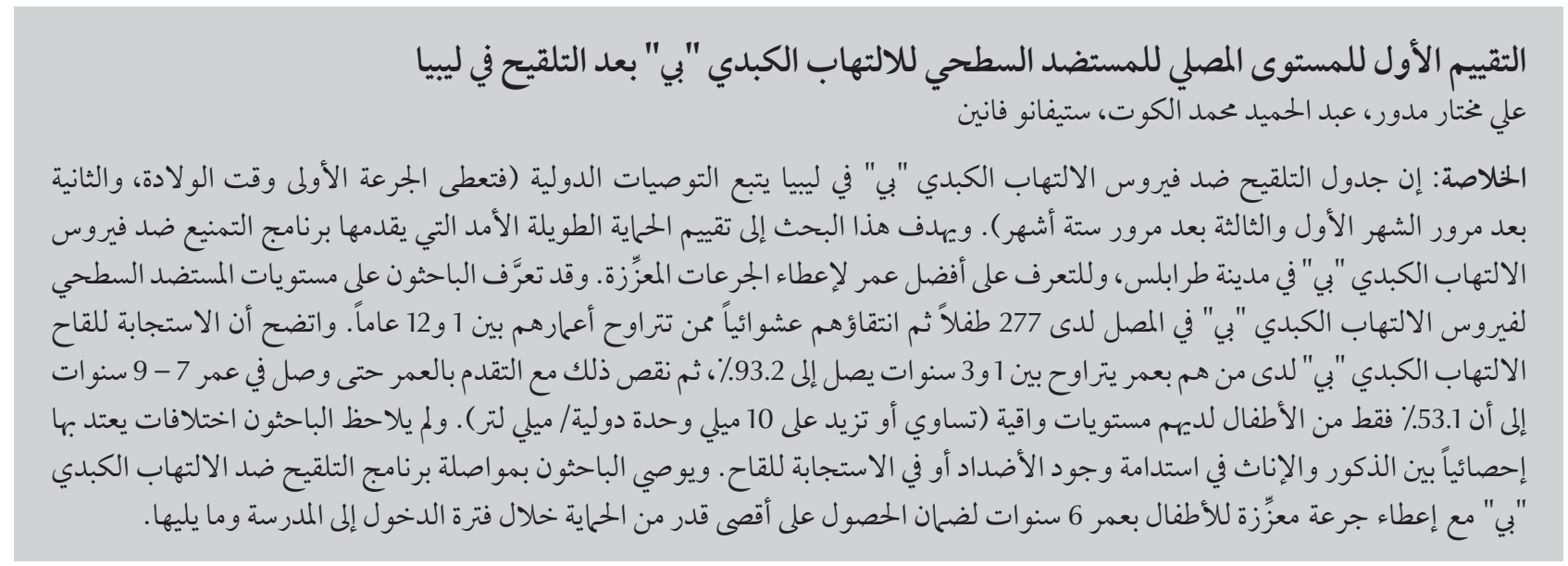

ABSTRACT The hepatitis B virus (HBV) vaccination schedule in Libya follows international recommendations (1st dose at birth, 2nd after 1 month and 3rd after 6 months). This research aimed to evaluate the long-term protection of the HBV immunization programme in Tripoli and to determine the best age to administer booster doses. Serum levels of hepatitis B surface antigen were determined in 277 randomly selected children aged 1-12 years. The response to HBV vaccine in 1-3-year-olds was 93.2\%, but this declined with age and at 7-9 years after initial vaccination only $53.1 \%$ of children had protective titres $(\geq 10 \mathrm{mIU} / \mathrm{mL})$. No significant differences between males and females in antibody persistence or response to vaccine were observed. We recommend continuing the HBV vaccination programme and that a booster dose be given to 6 -year-old children to ensure maximum protection during the period of school entry and beyond.

Première évaluation de la concentration sérique de l'antigène de surface du virus de l'hépatite B après la vaccination en Libye

RÉSUMÉ Le calendrier de vaccination contre le virus de I'hépatite B en Libye suit les recommandations internationales (première dose à la naissance, deuxième dose un mois après et troisième dose six mois après). La présente recherche visait à évaluer la protection à long terme apportée par le programme de vaccination contre le virus de I'hépatite B à Tripoli et à déterminer le meilleur âge pour administrer les doses de rappel. Les concentrations sériques de l'antigène de surface du virus de l'hépatite B ont été déterminés chez 277 enfants âgés de 1 à 12 ans sélectionnés aléatoirement. La réponse au vaccin contre le virus de l'hépatite B chez les enfants âgés de 1 à 3 ans était de 93,2 \%, mais déclinait avec l'âge et après une première dose, seulement 53,1 \% des enfants de 7 à 9 ans avaient des titres protecteurs $(\geq 10 \mathrm{mUI} / \mathrm{mL}$ ). Aucune différence significative n'a été observée entre les garçons et les filles pour la persistance des anticorps ou la réponse au vaccin. Nous recommandons de poursuivre le programme de vaccination contre le virus de l'hépatite B et d'administrer une dose de rappel aux enfants de 6 ans afin de garantir une protection maximale au moment de l'entrée à l'école et ultérieurement. 


\section{Introduction}

Approximately 2 billion people, about $33 \%$ of the world population, are infected by hepatitis B virus (HBV). Over 300 million among them are chronically infected, which represents about $5 \%$ of the population, and about a quarter of them suffers from the serious consequences of liver diseases such as chronic hepatitis, primary hepatocellular carcinoma and cirrhosis [1]. HBV kills 1-2 million people every year [2]. The hepatitis B surface antigen (HBsAg) carrier rate varies from less than 1\% in Europe to 20\% in sub-Saharan Africa.

The prevalence of disease among Libyans was $2.18 \%$ and $2.20 \%$ in 2004 and 2005 respectively [3]. Libya is considered an area of intermediate endemicity for HBV infection, and the frequency of $\mathrm{HBV}$ is lower among immunized people. The number of HBsAg carriers in Libya is estimated between 120000 and 150000 , and the infections have occurred mostly among high-risk behaviour people: those with a history of scarification (29.0\%), contact with hepatitis B patients (22.8\%), history of jaundice (19.0\%), family history of hepatitis B (10.7\%), history of blood transfusion $(9.0 \%)$ and multiple sexual partners (7.2\%) [4]. However, the exact number of infected people is not known, and therefore many people receive no counselling or treatment or even testing [4].

Despite the World Health Organization (WHO) recommendation to all countries to start $\mathrm{HBV}$ vaccination by 1997 [5], in Libya the neonatal vaccination programme against HBV started in 1993. Later on, age cohorts born in 1991-92 and 1989-90 were vaccinated by the vaccination campaigns in 2005 and 2006 respectively. The Libyan vaccination schedule follows WHO and Advisory Committee on Immunization Practices (ACIP) suggestions: 1st dose given at birth, the 2nd after 1 month and the 3rd after 6 months. The duration of protection provided by the vaccine in Libya is unknown and this study was carried out in order to evaluate the long-term protection of hepatitis $B$ vaccine and the need for booster doses.

\section{Methods}

\section{Sample}

The study was performed on 277 randomly selected children (156 boys and 125 girls) aged $1-12$ years from different areas of Tripoli. This is the capital city of Libya and different Libyan subgroups are represented in the population. All children received 3 doses of recombinant hepatitis $B$ vaccine at the birth, after 1 month and after 6 months.

Ethical approval was obtained from the Academy of Graduate Studies in Tripoli. All the samples were obtained after informed consent had been given; as patients were under age, approval was obtained from parents.

\section{Data collection}

Samples were collected from children in Alkadesia medical centre and Algla hospital in Tripoli between February and July 2009; $3 \mathrm{~mL}$ of venous blood was taken by venepuncture into heparinized tubes.

Anti-HBsAg quantification was performed at Al-Mubdeoun laboratory in Tripoli in October 2009. The sera were separated after clotting using centrifugation. Serum samples were stored at $-20^{\circ} \mathrm{C}$ until analyses were performed. Serological analyses were performed using bioMérieux mini VIDAS ${ }^{\circ}$ automated immunoassay chemistry system. BioMérieux VIDAS hepatitis B surface antibody (anti-HBs) total quick kit was used for the HBV antibody identification following the manufacturer's instruction. This assay combines an enzyme immunoassay sandwich method with a final fluorescent detection using the enzyme linked fluorescent assay technique.

\section{Analysis}

The children were analysed in 4 groups according to age: $1-3$ years (88 children), 4- 6 years (98 children), 7-9 years (49 children) and $10-12$ years (42 children). Statistical analyses were performed using the software SPSS, version 17.0.

\section{Results}

The results collected from the 277 children screened for anti-HBs showed that 89 had anti-HBs antibody $<10 \mathrm{mIU} /$ $\mathrm{mL}$, which is considered non-protective and 188 children showed a titre $\geq 10$ $\mathrm{mIU} / \mathrm{mL}$, which is considered protective. Of the 88 children aged $1-3$ years who received the 3 doses of vaccine 6 (6.8\%) did not show a positive response to the vaccination (Table 1) and $93.2 \%$ showed a positive response. At age 4-6 years $73.3 \%$ responded, at age $7-9$ years $60.0 \%$ and by age $10-12$ years only $25.0 \%$ had a positive response (Table $1)$.

Figure 1 shows that the response to vaccine (i.e. the percentage of children with a titre $\geq 10 \mathrm{mIU} / \mathrm{mL}$ ) and the anti-HBs titre declined linearly with age across the 4 age groups, from the highest response at ages $1-3$ years to lowest at $10-12$ years.

No significant differences were observed in the titre values between males and females, either in the response to vaccine or in the decrease of antibody titres across age groups ( $P=0.817$ and $P=0.386$ respectively) (Table 1).

\section{Discussion}

This study in Libya showed that only $6.8 \%$ of the 1-3-year-old cohort who received the 3 doses of vaccine did not respond positively to the vaccination. This result is slightly higher compared with the findings of other studies performed in Taiwan, Turkey, 


\begin{tabular}{|c|c|c|c|c|}
\hline $\begin{array}{l}\text { Table } 1 \text { Distribut } \\
\text { according to sex }\end{array}$ & y hep & surfa & dy (a & s) titre \\
\hline Sex/age group & & & tre & \\
\hline & & $/ \mathrm{mL}$ & & mL \\
\hline & No. & $\%$ & No. & $\%$ \\
\hline Males & & & & \\
\hline $1-3$ yrs & 3 & 6.3 & 45 & 93.7 \\
\hline $4-6 \mathrm{yrs}$ & 17 & 32.1 & 36 & 67.9 \\
\hline $7-9$ yrs & 15 & 51.7 & 14 & 48.3 \\
\hline $10-12$ yrs & 16 & 72.7 & 6 & 27.3 \\
\hline Females & & & & \\
\hline $1-3$ yrs & 3 & 7.5 & 37 & 92.5 \\
\hline $4-6$ yrs & 12 & 26.7 & 33 & 73.3 \\
\hline $7-9 \mathrm{yrs}$ & 8 & 40.0 & 12 & 60.0 \\
\hline $10-12$ yrs & 15 & 75.0 & 5 & 25.0 \\
\hline Both sexes & & & & \\
\hline $1-3$ yrs & 6 & 6.8 & 82 & 93.2 \\
\hline $4-6$ yrs & 29 & 29.6 & 69 & 70.4 \\
\hline $7-9 \mathrm{yrs}$ & 23 & 46.9 & 26 & 53.1 \\
\hline $10-12$ yrs & 31 & 73.8 & 11 & 26.2 \\
\hline
\end{tabular}

The Gambia and Palestine (Gaza) that show percentages of non-responders of $3.3 \%, 2.3 \%, 5 \%$ and $5.5 \%$ respectively [6-8]. Further studies in the future will be needed to identify the reason for lower immune responses (pathology, ethnicity, family history, etc.). The total positive response to hepatitis $B$ vaccine

among infants (93.2\%) confirmed a good vaccination coverage in Libya. This is in agreement with Egyptian data, which revealed a response rate of $93.3 \%$ 1 month after vaccination [9], and with data reported by the Ministry of Health in NewZealand [10] and Desombere et al. in Belgium [11], indicating a positive

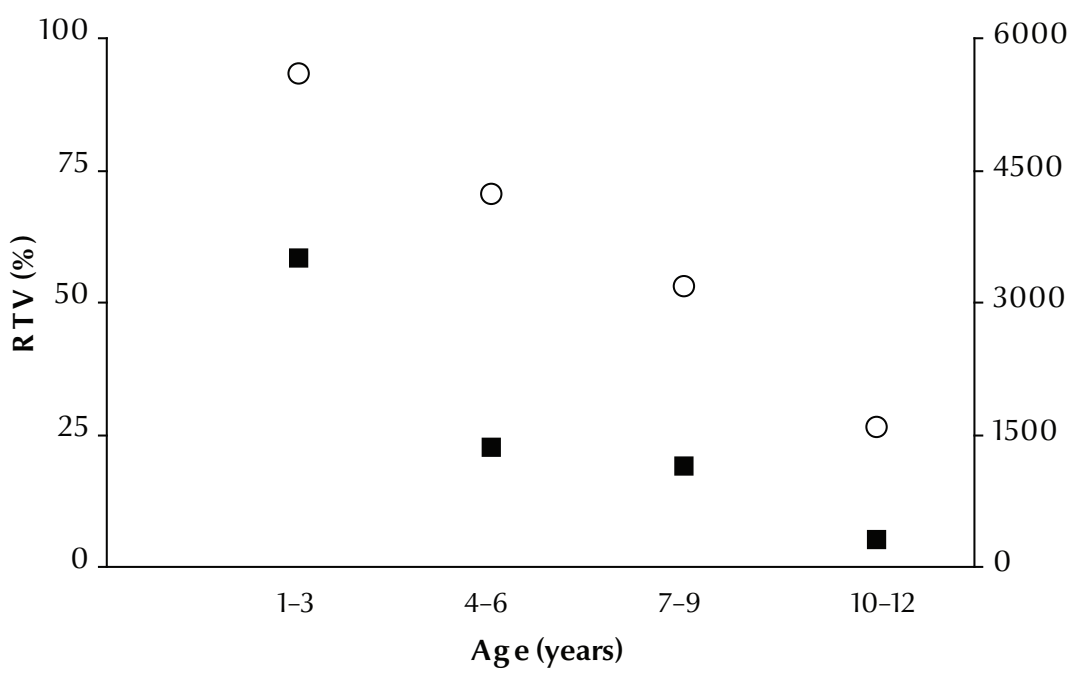

Figure 1 Hepatitis B surface antibody (anti-HBs) titre (black squares) and percentage response to vaccine (RTV) (white circles) according to age group of children (regression: $\boldsymbol{R}^{2}$ adjusted $=\mathbf{0 . 9 9 0}$ and 0.793 for titre and response to vaccine respectively) response in children varying from $90 \%$ to $95 \%$.

Different factors can affect the responsiveness to hepatitis $\mathrm{B}$ vaccine [12]. In general, variations in immune response among individuals, the age of the vaccine, differences in manufacturing and the timing of the $3 \mathrm{rd}$ vaccine dose administration are considered the main factors that can affect the response to vaccination [13]. Hadler et al. found that response to vaccination was improved with increasing age but also that the response was improved by increasing the time between doses to more than 7 months [14]. In contrast to this observation, Inskip et al. reported that the only additional factor which contributed to the response was the logarithm of the length of time between the first and the second dose of vaccine, with a longer interval resulting in a lower antibody level. So when there was a doubling of the interval between the first and second dose from 4 to 8 weeks the reduction in antibody level was approximately $12 \%$ [15].

Age-group analysis showed that the response to vaccine and the anti-HBs titre declined across the 4 age group cohorts, indicating a decrease in vaccine efficacy against infection with time. The titre decline observed in this study disagrees with a study from The Gambia, which is considered an HBV endemic country, that concluded that vaccination early in life can provide long-lasting efficacy [15]. In contrast, our findings are in agreement with the results of the vaccination of Iranian children, which is an intermediate prevalence country [1]. Research carried out in Egypt showed a faster rate in the waning of the titre than our finding: 5 years after vaccination the anti-HBs titre was 53.3\% [9]. In addition, a study performed in Senegal showed that the titre fell to $<10 \mathrm{mIU} /$ $\mathrm{mL}$ in $33 \%$ of children during the 5 th and 6 th years of life and the authors recommended the introduction of a booster 4th dose after 5 years in order to maximize the vaccination effect [16]. In 
general, the findings of previous studies suggest that the efficacy of hepatitis $B$ vaccine is variable depending on the country. This situation could be attributed to many reasons including: prevalence of hepatitis B disease, differences in immune response, endemicity, vaccination coverage, timing of vaccination, vaccination schedule, differences in vaccine synthesis, poor vaccine cold-chain storage and variations in the methods used to assay antibody titre [13].

Analyses carried out in Palestine, Alaska and The Gambia, which are considered highly endemic areas for HBV carriers, show a "long term" persistence of antibody as compared with other studies performed in the Islamic Republic of Iran, Egypt and Libya (this study), which are considered areas of intermediate HBV endemicity, and which showed a faster rate of antibodies decline. The immunization schedule might also play a role in determining anti-HBs levels and the time interval between doses appears to affect antibody levels [17]. Concerning this point, our results are in agreement with the findings of a study done in Egypt, in which a 2-, 4- and 6-month hepatitis $B$ vaccine schedule has been adopted, despite researchers recommending a new vaccination schedule at 1,2 and 9 months, to extend the persistence of antibody [18]. The 2 most-used schedules for the hepatitis $B$ vaccine are 1, 2 and 12 months and 0,1 and 6 months [17]. Da Villa et al. found that a higher level of protective anti-HBs was achieved when the vaccine dose was administered to 3-month-old children instead of 1-month-old infants [19], while Williams et al. suggested that the persistence of protection for a longer period takes place when the first vaccine dose is administered soon after birth [20]. The type of vaccine (plasma or yeastderived) also plays an important role in the response to vaccination and the persistence of its effects. Da Villa et al. found that the DNA recombinant vaccine has a higher titre level (97.6\%) as compared with plasma-derived vaccine $(80.4 \%)$. In addition, Floreani et al. found a slightly higher titre with plasma-derived vaccine than yeastderived vaccine $(87.8 \%$ and $81.6 \%$ respectively) [21]. Zuckerman et al. suggested that an elevate vaccine dosage may lead to the production of high levels of anti-HBs [22].

Some studies suggested that by beginning the first vaccination dose at a later age the persistence of anti-HBs might be improved as the prevalence of anti-HBs titre $\geq 10 \mathrm{mIU} / \mathrm{mL}$ ranged from $79 \%$ to $85 \%$ at $10-12$ years of age $[23,24]$. In addition, Petersen et al. found that antibody levels decreased most in individuals who received the vaccine before the age of 4 years [25]. These authors studied the results obtained after vaccination had been given at 2-3 months of age or later and showed a slower rate of decline of the titre compared with our study in which children received the 1st dose within the 1st weeks of life, as recommended by ACIP [25].

Research in the Islamic Republic of Iran showed that $60.9 \%$ of healthcare workers had anti-HBs titre $\geq 10$ $\mathrm{mIU} / \mathrm{mL} 10$ years after vaccination [26]. Furthermore, in the USA 47 out of 54 health professionals $(87 \%)$ showed anti-HBs response to anti-HBs $>10$ S/N RIA units 10 years after vaccination [27].

No significant sex differences were observed in our study in the response to vaccine or in the decrease of antibody titres across age groups. This finding is in agreement with other studies, indicating that in $\mathrm{HBV}$ vaccination programmes sex is not a variable that has to be considered in order to evaluate the efficacy of the campaign $[1,6-8,15]$.

\section{Conclusions}

This study showed a decreasing immunogenicity associated with increased age. Although $70.4 \%$ of the vaccinated children aged 4-6 years old were protected only half of the children (53.1\%) who had been vaccinated from birth had anti-HBs levels $\leq 10 \mathrm{mIU} / \mathrm{mL}$ 7-9 years after the last dose of vaccine was administered. Hepatitis B vaccine is highly immunogenic and immunization with hepatitis B vaccine in Libya showed a high response in infants aged $1-3$ years $(93.2 \%)$, which is likely to have a beneficial impact on HBV transmission in this age group. This study strongly suggests that continuation of the hepatitis B immunization programme would be beneficial in Libya, in line with findings from the available literature and the $\mathrm{WHO}$ recommendations that emphasize the importance of administering the 1st dose of the hepatitis B vaccine immediately after birth in order to avoid transmission of HBV during childhood.

The findings of this research have confirmed that the response to hepatitis B vaccine disappears over time. Therefore a booster dose might be necessary for children at least 6 years after the first vaccination to ensure maximum protection in the period of school entry and adulthood. This observation must be evaluated depending on the country, the endemicity of the disease and the condition and schedule of the immunization programme.

\section{Acknowledgements}

Funding: This research was funded by the Libyan Academy for graduate studies.

Competing interests: None declared. 


\section{References}

1. Kazemi A et al. Serum level of anti-hepatitis B surface antigen 10-12 years after hepatitis B vaccine at birth. Eastern Mediterranean Health Journal, 2008, 14(4):960-965.

2. Colin W et al. Hepatitis B virus infection: epidemiology and vaccination. Epidemiologic Reviews, 2006, 28:112-125.

3. Hepatitis B virus infection. Libyan epidemiological report, 2005. Tripoli, Libya, National Centre for the Prevention of Communicable and Endemic Diseases, and Control, 2005.

4. Abdul-Naser E. Hepatitis B infection in Libya: the magnitude of the problem. Libyan Journal of Infectious Diseases, 2008, 2:20-25.

5. Hepatitis B immunization. WHO position. Weekly Epidemiological Record, 1998, 73:329.

6. Hsu HM et al. Efficacy at a mass hepatitis B immunization program switching to recombinant hepatitis B vaccine: a population based study in Taiwan. Vaccine, 2001, 19:2825-2829.

7. Karaoglu L et al. Evaluation of the immune response to hepatitis $b$ vaccination in children aged $1-3$ years in Malatya, Turkey. New Microbiologica, 2003, 26:311-319.

8. Elian F, Shubair M. Evaluation of efficacy of hepatitis B vaccine in different age groups in Gaza. Islamic University Journal, 2006, 14:91-103.

9. El-Sawy H, Mohamed N. Long term immunogenicity and efficacy of a recombinant hepatitis B vaccine in Egyptian children. Eastern Mediterranean Health Journal, 1999, 5:922-932.

10. Immunization handbook 2006, Wellington, New Zealand, Ministry of Health, 2006.

11. Desombere I, Willems A, Leroux-Roels G. Response to hepatitis B vaccine: multiple HLA genes are involved. Tissue Antigens, 1998, 51:593-604.

12. Ramezani A et al. Is Any factor influence on hepatitis B vaccination response in hemodialysis patients? Internet Journal of Nephrology, 2006, 3: 10.5580/2649.

13. Children's vaccines-safety first. Geneva, World Health Organization, 1999.

14. Hadler $\mathrm{S}$ et al. Effect of timing of hepatitis B vaccine doses on response to vaccine in Yucpa Indians. Vaccine Journal, 1989, 7:106-110.

15. Inskip HM et al. Hepatitis B vaccine in the Gambian Expanded Programme on Immunization: factors influencing antibody response. International Journal of Epidemiology, 1991, 20(3):764-769.

16. Coursaget $P$ et al. Seven-year study of hepatitis B vaccine efficacy in infants from an endemic area (Senegal). Lancet, 1986, 2:1143-1145.

17. Combined hepatitis B vaccines. Proceedings of the Viral Hepatitis Prevention Board meeting. St Julians, Malta, Viral Hepatitis Prevention Board, 2001.

18. Shaaban F et al. Long-term immunity to hepatitis B among a sample of fully vaccinated children in Cairo, Egypt. Eastern Mediterranean Health Journal, 2007, 13:750-757.

19. Da Villa G et al. Persistence of anti-HBs in children vaccinated against viral hepatitis $B$ in the first year of life: follow-up at 5 and 10 years. Vaccine, 1996, 14(16): 1503-1505.

20. Williams IT et al. Long term antibody response to hepatitis $B$ vaccination beginning at birth and to subsequent booster vaccination. Pediatric Infectious Diseases Journal, 2003, 22(2):157-163.

21. Floreani A et al. Long-term persistence of anti-HBs after vaccination against HBV: an 18-year experience in health care workers. Vaccine, 2004, 22(5-6):607-610.

22. Zuckerman AJ. Effect of hepatitis B virus mutants on efficacy of vaccination. Lancet, 2000, 355:1382-1384.

23. Lemon SM, Thomas DL. Vaccines to prevent viral hepatitis. New England Journal of Medicine, 1997, 336:196-204.

24. Yuen MF. Twelve-years follow-up of a prospective randomized trial of hepatitis B Recombinant DNA yeast vaccine versus plasma-derived vaccine without booster doses in children. Hepatology, 2003, 29:924-927.

25. Petersen KM et al. Duration of hepatitis b immunity in low risk children receiving hepatitis B vaccinations from birth. Pediatric Infectious Disease Journal, 2004, 23:650-655.

26. Saberifiroozi M, Gholamzadeh S, Serati S. The long-term immunity among health care workers vaccinated against hepatitis B virus in a large referral hospital in southern Iran. Archives of Iranian Medicine, 2006, 9:204-207.

27. Krugman S, Davidson M, Hepatitis B. Vaccine: prospects for duration of immunity. Yale Journal of Biology and Medicine, 1987, 60:333-339. 